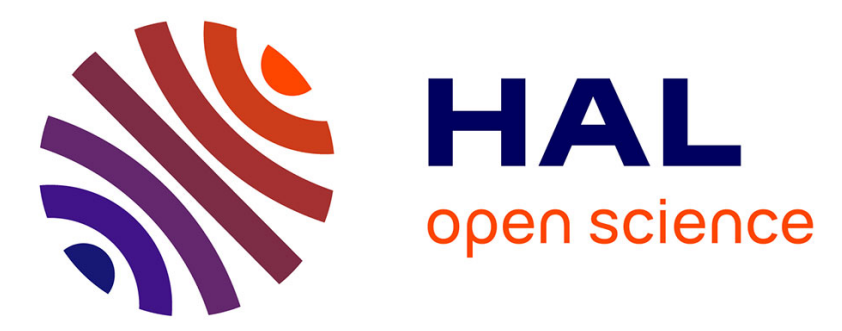

\title{
Hepatitis B virus (HBV)-derived DRB1*0101-restricted CD4 T-cell epitopes help in the development of HBV-specific CD8+ $\mathrm{T}$ cells in vivo.
}

Florence Bayard, Silvina Malmassari, Qiang Deng, Yu-Chun Lone, Marie-Louise Michel

\section{To cite this version:}

Florence Bayard, Silvina Malmassari, Qiang Deng, Yu-Chun Lone, Marie-Louise Michel. Hepatitis B virus (HBV)-derived DRB1*0101-restricted CD4 T-cell epitopes help in the development of HBVspecific CD8+ T cells in vivo.. Vaccine, 2010, epub ahead of print. 10.1016/j.vaccine.2010.03.026 . pasteur-00474284

\section{HAL Id: pasteur-00474284}

https://hal-pasteur.archives-ouvertes.fr/pasteur-00474284

Submitted on 19 Apr 2010

HAL is a multi-disciplinary open access archive for the deposit and dissemination of scientific research documents, whether they are published or not. The documents may come from teaching and research institutions in France or abroad, or from public or private research centers.
L'archive ouverte pluridisciplinaire HAL, est destinée au dépôt et à la diffusion de documents scientifiques de niveau recherche, publiés ou non, émanant des établissements d'enseignement et de recherche français ou étrangers, des laboratoires publics ou privés. 
3 Hepatitis B virus (HBV)-derived DRB1*0101-restricted CD4 T-cell epitopes

4 help in the development of HBV-specific CD8+ T cells in vivo

BAYARD Florence, ${ }^{1,2}$ MALMASSARI Silvina, ${ }^{1,2}$ DENG Qiang, ${ }^{1,2,3}$ LONE Yu-Chun, ${ }^{4}$

9 MICHEL Marie-Louise ${ }^{1,2, *}$

101 Institut Pasteur, Laboratoire Pathogenèse des virus de l'hépatite B, département de

11 Virologie; 75015 Paris, France

12 INSERM, U 845, Centre de recherche “croissance et signalisation”, Faculté de Médecine

13 Paris Descartes ; 75015 Paris, France

144 INSERM, U 542, hôpital Paul Brousse; 94807 Villejuif, France

15

16 Running title : Hepatitis B virus helper epitopes for in vivo CD8 response

17 Keywords: $\mathrm{T}$ cells, epitope, vaccination

18

19 Abstract word count: 100

20

${ }^{1}$ 3, Present address: Unit of Tumor Virus, Institut Pasteur of Shanghai; 200025 Shanghai, China 


\section{Abstract}

We previously identified two HLA-DRB1*0101-restricted epitopes in hepatitis B 3 virus (HBV) X protein (HBx) and in HBV envelope proteins (preS2). To evaluated their help

4 in the development of CD8+ T-cell responses, mice transgenic for human class I and class II 5 HLA molecules were immunized with HBV-T helper constructs. The preS2 epitope favored a 6 well-balanced response with CD4+ and CD8+ T cells producing IFN- $\gamma$, IL-2 and TNF- $\alpha$. The 7 response was focused on $\mathrm{CD} 8+\mathrm{T}$ cells with the $\mathrm{HBx}$ epitope. Fine characterization of helper 8 activities may meet clinical needs in terms of enhancing the potency of preventive or 9 therapeutic polyepitope vaccines.

\section{$2 *$ Contact Information}

Dr. Marie-Louise Michel

Laboratoire Pathogenèse des virus de l'hépatite $B$

Bâtiment Lwoff, Institut Pasteur

28, rue du Docteur Roux75724 PARIS CEDEX 15

Tel: $(+33)$ 1.45.68.88.49

Fax: (+33) 1.40.61.38.41

E-mail: marie-louise.michel@pasteur.fr 


\section{Introduction}

Hepatitis B virus (HBV) is a non-cytopathic virus that chronically infects between 350 and 400 million people throughout the world [1]. Childhood HBV infection leads to chronicity in more than $95 \%$ of cases, whereas $95 \%$ of immuno-competent infected adults clear the virus. The establishment of chronicity is multifactorial, involving both viral factors and defects in the immune response. The elimination of HBV after acute infection is characterized by a strong polyclonal and multispecific $\mathrm{T}$ cell immune response and the production of Th1 cytokines. By contrast, chronically HBV-infected individuals display a weak or undetectable immune response specific for HBV antigens and are unable to clear the virus, producing Th2 cytokines in the liver. In these patients, HBV-specific CD4+ and CD8+ $\mathrm{T}$ cells have impaired functions affecting their proliferative capacity, the secretion of Th1 cytokines and cytotoxicity $[2,3]$. HBV-specific Th1 CD4+ T cells are key elements in HBV clearance because they support the development of HBV-specific CD8+ T cells secreting anti-viral cytokines such as IFN- $\gamma$ and TNF- $\alpha$, and CD8+ T cells with a cytolytic function [4]. CD4+ $\mathrm{T}$ cells are also required to activate $\mathrm{B}$ cells to produce antibodies that can neutralize free viral particles and prevent reinfection by HBV. Moreover, antigen-specific helper CD4+ $\mathrm{T}$ cells not only help in the development of strong effector CD8+ $\mathrm{T}$ cell responses but also in establishing and maintaining memory CD8+ T cells [5].

$\mathrm{HBV}$ is an enveloped virus with a small, circular and partially double-stranded genome of $3.2 \mathrm{~kb}$. Four overlapping reading frames encode the viral polymerase, the large, middle and small envelope proteins, the capsid and the transactivating hepatitis B X protein (HBx) [6]. We recently identified a promiscuous T helper epitope within the HBx protein that was recognized by CD4+ T cells from HBV-chronically infected patients with multiple HLADR restrictions [7]. Patients with HBx-specific T cells were in the low replicative phase of the 
1 disease whereas this response was undetectable in patients in the replicative phase. These T

2 cells mostly secreted IFN- $\gamma$ but not IL-10, and may have contributed to the control of viral

3 replication. In addition, an HLA-DRB1*0101-restricted epitope was identified in the preS2

4 domain of the HBV middle envelope protein in HLA-DR1-vaccinated individuals and in

5 HLA-DRB $1 * 0101$ transgenic, H-2 class II KO $\left(\mathrm{IA} \beta^{\mathrm{b}-/-}\right)$ mice immunized with recombinant

6 HBV vaccine or DNA encoding envelope proteins. T cells specific to this epitope had

7 proliferation capacity and secreted IFN- $\gamma[8]$.

The aim of the present study was thus to better characterize the function of the CD4+

9 T cells specific to these two HBV-derived epitopes, and to analyze their helper potential regarding the development of an efficient $\mathrm{CD} 8+\mathrm{T}$ cell response in vivo. To achieve this goal, the HBx- or preS2-derived helper epitopes, referred to as X26 and S238 respectively, were inserted in invariant (Ii) chain-based constructs in which the class-II-associated Ii peptide (CLIP) was replaced with each of the CD4+ T cell epitopes, thus allowing their presentation through the MHC class II pathway $[9,10]$. To monitor CD8+ T cell responses, two reporter HLA-A*0201-restricted epitopes from the HBV small envelope protein were inserted downstream of the Ii chain. HLA-A*0201/DRB1*0101 transgenic, H-2 class I/class II KO mice were immunized with the Ii chain-based DNA constructs. As a control, a construct harboring the promiscuous Pan HLA-DR (PADRE) epitope [11] designed to bind multiple HLA class II molecules, was employed.

Our results show that HBV-derived helper epitopes were significantly more efficient

21 than the reference PADRE epitope in inducing in vivo IFN- $\gamma$-secreting CD8+ T cells specific to the HBV-derived HLA-A*0201-restricted reporter epitopes. CD4+ T cells specific to PADRE and S238 epitopes secreted IFN- $\gamma$, IL-2 and TNF- $\alpha$ cytokines. In contrast, cytokine secretion by CD4+ T cells specific to the promiscuous epitope X26 were not detectable in 
1 immunized mice. Nevertheless, the vector encoding the HBx-epitope efficiently activated

$2 \mathrm{CD} 8+\mathrm{T}$ cells specific to the two reporter epitopes.

3

These results underline the relevance of using HLA-transgenic mice and Ii chain-

4 based vectors to test the helper potential of specific CD4+ T cell epitopes in vivo. Moreover,

5 these findings may have clinical implications in terms of enhancing the potency of

6 polyepitope vaccines and improving the antigen-specific immune response during preventive

7 or therapeutic vaccination.

8 


\section{2. Material and methods}

\subsection{Vectors}

4 The DNA constructs used during this study derived from the pIRES2-EGFP vector (BD

5 Biosciences, Le pont de Claix, France). To obtain the pIC-Empty construct, a cDNA encoding

6 the N-terminal part of the Ii invariant chain (aa 1 to 82 ) was fused to the sequence encoding

7 two HLA-A*0201-restricted hepatitis B surface (HBs)-derived CD8+ T cell reporter epitopes:

8 HBs 335-343 (WLSLLVPFV) and HBs 348-357 (GLSPTVWLSV) separated by a spacer

9 (GPGPG) to facilitate proteasome cleavage. This cDNA was inserted between the NheI and

10 BamHI restriction sites in the multiple cloning site of the plasmid (Figure 1A). Three 11 synthetic codon-optimized cDNAs encoding PADRE (AKFVAAWTLKAAA), X26 (EIRLKVFVLGGCRHK) or S238 (TTFHQTLQDPRVRGL) T helper epitopes were inserted

13 in frame at aa 82 of the invariant chain upstream of the region encoding the reporter epitopes, 14 in order to obtain the pIC-PADRE, pIC-X26 and pIC-S238 constructs, respectively (Figure 15 1B). Plasmids were purified using Qiagen DNA purification columns (Endofree Plasmid Kit; Qiagen, Hilden, Germany). Vectors were suspended at $1 \mathrm{mg} / \mathrm{ml}$ in endotoxin-free PBS (Sigma, St Quentin Fallavier, France).

\subsection{Peptides}

Stock solutions of all synthetic peptides were produced at $1 \mathrm{mg} / \mathrm{ml}$ in either water or $20 \%$ DMSO, according to the supplier's instructions. The peptides were used individually for the in vitro stimulation of splenocytes and in ELISPOT assays. All peptides, with a minimum purity of $80 \%$, were purchased from NeoMPS (Strasbourg, France). 
1 The HLA-A*0201/DRB1*0101 transgenic, H-2 class I/class II KO mice used during this 2 study [12] were housed in the animal facilities of the Pasteur Institute. Groups of 6 to 10 3 week-old female mice were primed and then boosted 3 weeks later with the different DNA 4 constructs. Intramuscular nucleic acid immunizations were performed under anesthesia by $5 \quad$ injecting $100 \mu \mathrm{g}(1 \mathrm{mg} / \mathrm{ml})$ of plasmid DNA into regenerating (i.e. cardiotoxin-treated) 6 tibialis anterior muscles, as previously described [13]. Non-immunized mice served as 7 control for ELISPOT assays. All animal procedures were performed in compliance with approved protocols and guidelines for the proper use and care of laboratory animals.

\subsection{Pentamer staining}

11 Pentameric peptide-HLA class I complexes (pentamers; ProImmune, Oxford, UK) were used according to the manufacturer's instructions. Four $\mu 1$ of PE-labeled pentamer HBs 335-343 and allophycocyanin (APC)-labeled pentamer HBs 348-357 per well were added to 1 million splenocytes in round-bottomed 96-well plates and then incubated at room temperature for 10 minutes. $4 \mu \mathrm{l}$ of APC-labeled pentamer HBV core 18-27 were used as a control. The cells were then washed twice with PBS 1X, BSA 1\%, Azide $0.01 \%$. Cell surface staining was performed using anti-CD3-PE-Cy7 (clone 145-2C11, Clinisciences SA, Montrouge, France), anti-CD8-PerCP (clone 53-6.7, BD Biosciences), anti-CD4-PE or -FITC (clone GK1.5, BD Biosciences), and a viability marker (LIVE/DEAD fixable near-IR dead cell stain kit, Invitrogen, France). The cells were incubated for 30 minutes at $4^{\circ} \mathrm{C}$, washed again and fixed 21 with $1 \%$ paraformaldehyde. At least 250,000 lymphocyte-gated events were acquired on a 22 FACSCanto flow cytometer (BD Biosciences) and analyzed with FlowJo software (Tree star, Inc., Ashland, Or, USA). Values were considered to be positive when at least 15 pentamerpositive $\mathrm{CD} 3+\mathrm{CD} 8+\mathrm{T}$ cells were counted, corresponding to $0.2 \%$ of $\mathrm{CD} 3+\mathrm{CD} 8+\mathrm{T}$ cells, and 
1 if this percentage was at least twice the percentage obtained with pentamer HBV core 18-27

2 staining.

3

4

5

\subsection{IFN- $\gamma$ and IL-2 ELISPOT assays}

IFN- $\gamma$ - and IL-2-producing T cells amongst the splenocytes were quantified by ELISPOT after peptide stimulation for 24 hours, as previously described [14]. Briefly, sterile nitrocellulose MSIP 96-well plates (Millipore, Bedford, MA) were pre-wetted for 1 minute

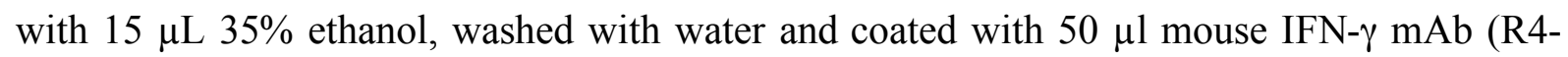
6A2; $5 \mu \mathrm{g} / \mathrm{ml}$; BD Bioscience) or $50 \mu 1$ mouse IL-2 mAb (1A12; $5 \mu \mathrm{g} / \mathrm{ml}$; Mabtech $\mathrm{AB}$, Stockholm, Sweden) in $0.1 \mathrm{M}$ bicarbonate buffer ( $\mathrm{pH} 9.6)$ overnight at $4^{\circ} \mathrm{C}$. Freshly isolated splenocytes were incubated with individual peptides at $2 \mu \mathrm{g} / \mathrm{ml}$ in complete $\alpha$-MEM medium [14]. Wells containing cells in culture medium were used as negative controls to determine background levels. A Bioreader 4000 (BioSys) counter was used to score the number of spots. Each cell population was titrated in triplicate. The response was considered positive if the median number of spot-forming cells (SFC) in triplicate wells was at least twice that observed in control wells containing medium, and at least 20 SFC per million splenocytes were detected after background subtraction.

\subsection{Intracellular staining}

For CD107a and IFN- $\gamma$ co-staining, 1 million splenocytes were incubated in the presence of anti-CD107a-FITC (clone 1D4B, BD Biosciences), monensin (2 $\mu \mathrm{g} / \mathrm{ml}$, Clinisciences SA), brefeldin A (5 $\mu \mathrm{g} / \mathrm{ml}$, Sigma), CD28 (1 $\mu \mathrm{g} / \mathrm{ml}$, clone 37-51, BD Biosciences), CD49d (1 $\mu \mathrm{g} / \mathrm{ml}$, clone R1.2, BD Biosciences) and peptide HBs 348-357 or HBs 335-343 (2 $\mu \mathrm{g} / \mathrm{ml})$ or medium for 4 hours at $37^{\circ} \mathrm{C}$, under $5 \% \mathrm{CO} 2$. For TNF- $\alpha$, IFN- $\gamma$ and IL-2 staining, 1 million splenocytes were incubated in the presence of brefeldin A (2 $\mu \mathrm{g} / \mathrm{ml}$, Sigma) and $\mathrm{T}$ helper 
1 peptides $(2 \mu \mathrm{g} / \mathrm{ml})$ or medium for 4 hours at $37^{\circ} \mathrm{C}$, under $5 \% \mathrm{CO} 2$. After washing, the cells

2 were incubated with the viability marker, anti-mouse CD8-PerCP-, CD4-PE- or CD4-APC-

3 H7- and CD3-PE-Cy7- or APC- (clone 145-2C11, BD Biosciences) conjugated antibodies for

430 minutes at $4{ }^{\circ} \mathrm{C}$ and then washed again. For intracellular staining, spleen cells were fixed,

5 permeabilized and incubated with anti-mouse IFN- $\gamma$ - APC or -PE antibodies (clone XMG1.2,

6 BD Biosciences), with anti-mouse IL-2-PE (clone JE56-5H4, BD Biosciences) or with anti-

7 mouse TNF- $\alpha$-FITC-antibodies (clone MP6-XT22, BD Biosciences) for 30 minutes at $4{ }^{\circ} \mathrm{C}$

8 and washed again prior to fixation. At least 200,000 lymphocyte-gated events were acquired

9 on a FACS Canto flow cytometer (BD Biosciences) and analyzed with FlowJo software (Tree

10 star, Inc., Ashland, Or, USA). For TNF- $\alpha$ staining, values were considered positive when the

11 percentage of TNF- $\alpha+C D 3+C D 4+T$ cells was twice that of the background obtained with the

12 medium alone.

$14 \quad$ 2.7. In vivo cytotoxic assay

15 Naive syngenic splenocytes were pulsed with HBs 335-343, HBs 348-357 or Core 18-27 peptides $\left(10 \mu \mathrm{g} / \mathrm{mL} ; 1\right.$ hour $\left.; 37^{\circ} \mathrm{C}\right)$ and respectively labeled with $0.25,1$ or $4 \mu \mathrm{M}$ of CFSE 17 (Invitrogen). $\mathrm{CFSE}^{\text {low }}, \mathrm{CFSE}^{\text {int }}$ and $\mathrm{CFSE}^{\text {high }}$-labeled cells were washed with PBS and mixed at a 1:1 ratio $\left(10^{7}\right.$ cells of each population in $100 \mu \mathrm{L}$ of PBS). Labeled splenocytes were then injected intraveinously into immunized mice 7 days after the second injection of DNA. As control CFSE-labeled cells were injected in naïve (non-immunized) mice to calculate background level of lysis. Twenty hours later, at least 30,000 CFSE positive cells remaining in the spleen were acquired on a FACScalibur flow cytometer (BD Biosciences) and analyzed with FlowJo software (Tree star, Inc., Ashland, Or, USA). 
1 The Kruskall-Wallis test followed by the Mann-Whitney test were used to compare groups of

2 mice and to calculate the $p$ values indicated in the Figures and Table. The Fisher's exact test 3 was used to compare the frequency of responder mice. Values were considered significant at a 4 level of $p<0.05$. Statistical analyses were performed using Prism 5 GraphPad Software. 5 Correlations between CD4+ and CD8 $+\mathrm{T}$ cell responses were analyzed using the Pearson's 6 correlation coefficient (r). 


\section{3. Results}

\subsection{Invariant chain-based DNA vectors encoding Thelper epitopes}

We had previously characterized a HLA-DRB $1 * 0101$-restricted epitope in HBV envelope (S238, [8]) and a promiscuous epitope in HBx protein that is able to bind (amongst others) the HLA-DRB1*0101 molecule (X26, [7]). As a reference T helper epitope we used PADRE that had previously been designed as a universal $\mathrm{T}$ helper epitope [11], for which the immune response is well documented. To evaluate the efficiency of these $\mathrm{T}$ helper epitopes in providing help in the development of $\mathrm{CD} 8+\mathrm{T}$ cell responses, we constructed DNA vectors based on the mouse Ii chain. The natural Ii chain encodes the CLIP peptide (aa position 85101), which binds the MHC class II peptide-binding groove and allows the exchange with class II peptides to be presented in association with the MHC class II molecule. In a basic pIC-Empty construct, a cDNA encoding the N-terminal part of Ii chain was fused to the sequence of two HLA-A*0201-restricted HBs-derived CD8+ T cell reporter epitopes, HBs 335-343 [15, 16] and HBs 348-357 [15, 17] (Fig. 1A). In three other constructs, synthetic codon optimized cDNAs encoding PADRE, X26 or S238 T helper epitopes were inserted in frame downstream of aa 82 of the Ii chain in order to improve their transport to the endoplasmic reticulum, and their association and presentation by MHC class II molecules. The $\mathrm{T}$ helper epitopes were thus upstream of the region encoding the HLA-A2-reporter epitopes. We refer to the vectors carrying these CD4+ epitopes as $\mathrm{T}$ helper constructs (Fig. 1B).

3.2. Ex vivo detection of HBs 348-357- and HBs 335-343-specific CD8+ $T$ cells in mice immunized with the pIC constructs.

To determine the ability of the selected DRB1*0101 epitopes to provide help in the CD8+ T cell response specific to the reporter epitopes, transgenic mice expressing human HLA- 
$1 \quad \mathrm{~A}^{*} 0201$ and HLA-DRB1*0101 but deficient in H-2 class I and II molecules were immunized

2 twice with $\mathrm{T}$ helper versus empty constructs via the intramuscular route. To enable

3 immunological assays, spleen cells were harvested 10 days after the second injection. The

4 number of circulating peptide-specific CD8+ T cells was quantified by pentamer staining,

5 which enables the detection of specific T cells regardless of the cytokine produced.

6 Pentamer HBs 348-357-positive CD8+ T cells were found in mice immunized with pIC-

7 PADRE, pIC-X26, pIC-S238 and pIC-Empty (Fig.2A). The number of mice with pentamer-

8 positive $\mathrm{T}$ cells (responder mice) was significantly lower (4/22 tested) amongst those

9 immunized with the pIC-Empty vector compared with mice immunized with $\mathrm{T}$ helper constructs $(p<0.0001)$. The number of responder mice was significantly higher in pICPADRE- and pIC-S238- immunized groups compared with pIC-X26 (Table 1).

12

Regarding the magnitude of the responses, the percentage of pentamer HBs 348-357-positive CD8+ $\mathrm{T}$ cells did not differ significantly between responder mice immunized with $\mathrm{T}$ helper constructs (Table 1). A representative pentamer HBs 348-357 staining is shown in Fig. 2B.

Concerning the HBs 335-343 reporter epitope, we found specific pentamer-positive CD8+ T cells in mice immunized with pIC-Empty (5/17 mice), pIC-X26 (8/18 mice) and pIC-S238 (1/14) but not with pIC-PADRE (Fig. 2C). This response remained weaker (mean around 0.5\% pentamer HBs 335-343-positive CD8+ T cells) than that observed with pentamer HBs 348-357 (mean around 1\% pentamer HBs 348-357-positive CD8+ T cells). Interestingly, and as shown in Fig. 2C, mice immunized with pIC-X26 had statistically more HBs 335-343specific CD8+ T cells than mice immunized with pIC-Empty. Therefore, circulating CD8+ T cells specific to the two reporter epitopes were detected after the pentamer staining of splenocytes from responder immunized mice. However, these responses mostly focused on the HBs 348-357 reporter epitope. 
1 3.3. Activation of IFN- $\gamma$ - and IL-2-secreting CD8+T cells in mice immunized with $H B V$ -

derived T helper epitope constructs.

Once the presence of CD8+ T cells specific to the reporter epitopes had been demonstrated, their function was then investigated. Ex vivo ELISPOT assays were used to detect IFN- $\gamma$ - and IL-2-secreting T cells after overnight stimulation with HBs-derived reporter peptides (Fig. 3 and Fig. 7). HBs 348-357 stimulation activated IFN- $\gamma$-secreting T cells in spleen cells from mice immunized with pIC-Empty, pIC-PADRE, pIC-X26 and pIC-S238 (Fig. 3 A). While the number of responder mice was not significantly different after immunization with the four constructs (Fisher's exact test, Table 1), the frequency of IFN- $\gamma$-secreting HBs 348-357specific T cells was significantly higher using the pIC-X26 and pIC-S238 vectors than with the vector encoding the reference peptide PADRE or pIC-Empty (see $p$ values on Table 1 and Fig.3A). This confirmed the effective help provided to development of the CD8+ $\mathrm{T}$ cell response by these two HBV-derived $\mathrm{T}$ helper epitopes. IFN- $\gamma$-secreting $\mathrm{T}$ cells specific to HBs 335-343 were only detected in a few mice immunized with pIC-Empty (2/27 tested; 84 and 61 SFC per million splenocytes), pIC-X26 (2/30; 20 and 29 SFC per million splenocytes) or pIC-S238 (1/20; 24 SFC per million splenocytes), but not with pIC-PADRE (Fig. 3B). Differences between groups were not significant. In summary, these results indicate that X26 and S238 HLA-DRB1*0101-restricted T helper epitopes were more efficient than PADRE in providing help for the induction of CD8+ T cells directed to the HBs 348-357 epitope, and particularly in stimulating IFN- $\gamma$ secretion.

\subsection{HBs 348-357-specific CD8+ T cells express degranulation marker and are cytotoxic.}

In order to investigate further the function of the HBs-specific CD8+ T cells, CD107a labeling was performed as a marker of degranulation and cytotoxicity [18]. CD8 $+\mathrm{T}$ cells expressing CD107a and IFN- $\gamma$ were found in mice immunized with pIC-PADRE, pIC-X26 
1 and pIC-S238 constructs four hours after either HBs 348-357 or HBs 335-343 stimulation. A

2 representative example of the staining of spleen cells with CD107a and IFN- $\gamma$ after pIC-S238

3 helper construct immunization is shown in Fig. 4 A. The mean percentage of CD8+ T cells

4 secreting IFN- $\gamma$ and expressing CD107a was higher for cells specific to the HBs 348-357

5 epitope compared to cells specific to the HBs 335-343 in splenocytes from mice immunized with pIC-S238, pIC-X26 and pIC-PADRE (Fig. 4B). In addition, cytolytic function of splenocytes was assessed in an in vivo cytotoxic assay. As an example, mice that were immunized with pIC-S238 helper construct efficiently lysed target splenocytes pulsed with peptide HBs $348-357$ as reflected by the in vivo clearance of $>50 \%$ of $\mathrm{CFSE}^{\text {int }}$ targets by $20 \mathrm{~h}$, but not those from the co-transferred population pulsed with the control peptide $\left(\mathrm{CFSE}^{\text {high }}\right)$ or with the HBs 335-343 peptide (CFSE ${ }^{\text {low }}$ ) (see Fig. 4C). These results show that primed CD8+ T cells specific to HBs 348-357 were functional cytotoxic T cells. specific to the Thelper epitopes.

In order to analyze the potency of these constructs in activating specific CD4+ $\mathrm{T}$ cells, splenocytes from immunized mice were stimulated ex vivo with the helper peptide corresponding to the each construct. The secretion of IFN- $\gamma$ and IL-2 by specific T cells was assessed by ELISPOT assays, and the phenotype of IFN- $\gamma$-producing cells was confirmed by intracellular staining, cell surface labeling and FACS analysis (Fig. 5). As a control, splenocytes from non-immunized mice and from mice immunized with pIC-Empty were stimulated with PADRE, S238 and X26 epitopes, and as expected, no cytokine secretion was 23 observed (data not shown).

24 Mice immunized with pIC-PADRE and pIC-S238 respectively developed PADRE-specific or 
1 were produced by CD4+ T cells as shown by FACS analysis for a representative mouse

2 immunized with pIC-Padre (Fig. 5C). By contrast, neither IFN- $\gamma$ - nor IL-2-secreting X26-

3 specific $\mathrm{T}$ cells were detected in a total of 24 mice immunized with pIC-X26. After PADRE

4 or S238 peptide stimulation, neither the frequency of responder mice nor the number of IFN-

$5 \quad \gamma$-secreting T cells differed statistically when mice were immunized with pIC-PADRE or pIC-

6 S238 (Fig. 5A). However, PADRE epitope activated a significantly higher number of IL-2-

7 secreting T cells, as measured by the mean of SFC compared with the S238 epitope ( $p=0.001$,

8 Table 1).

9 To further investigate the profile of cytokines secreted by PADRE-, S238- and X26-specific T

10 cells, TNF- $\alpha$ production by CD4+ T cells was tested by intracellular staining. Fig. 6 shows

11 that mice immunized with pIC-PADRE and pIC-S238 respectively developed PADREspecific or S238-specific TNF- $\alpha$-secreting CD4+ T cells (Table 1). The mean percentages of 13 TNF- $\alpha$-secreting CD3+CD4+ T cells were low, and no statistical difference was observed 14 after immunization with the two constructs. No TNF- $\alpha$ was found after stimulation with X26 peptide in 6 mice that received pIC-X26, thus raising the question as to whether other 16 cytokines might be produced. Neither IL-4 nor IL-10 were detected in ELISPOT assays 17 following stimulation with X26 peptide (data not shown).

18 These results show that ex vivo stimulation with PADRE and S238 peptides led to IFN- $\gamma$, IL192 and TNF- $\alpha$ secretion by CD4+ T cells from mice immunized with the corresponding $\mathrm{T}$ 20 helper constructs. However, despite the efficient activation of IFN- $\gamma$-secreting CD8+ T cells 21 after the immunization of mice with the vector containing the X26 epitope, no X26-specific CD4+ T cells were detectable under our experimental conditions. 
1 The relative frequencies of IFN- $\gamma$ - and IL-2-secreting peptide-specific CD8+ and CD4+ T

2 cells are summarized in Fig. 7. The CD8+ T cell response was clearly focused on the reporter 3 epitope HBs 348-357 (compare Fig. 7A and 7B). Mice immunized with pIC-S238 mounted a

4 large panel of functional T cells including both CD8+ and CD4+ T cells that secreted IFN- $\gamma$ 5 and IL-2 (Fig. 7A). For the S238 T helper epitope, a positive correlation was found between 6 the number of IFN- $\gamma$-secreting CD8+ T cells and the number of IFN- $\gamma$ - secreting CD4+ T 7 cells $(\mathrm{r}=0.45, \mathrm{p}=0.044)$. By contrast, in pIC-PADRE-immunized mice, the immune response 8 mainly focused on the PADRE epitope as the intensity of the HBs 348-357-specific CD8+ T 9 cell response was similar to that observed in mice immunized with pIC-Empty (Fig. 3 and 10 Fig. 7A). On the other hand, immunization with the pIC-X26 vector led to a strong HBs 34811 357-specific IFN- $\gamma$-CD8 + T cell response but no detectable IL-2, IFN- $\gamma$ and TNF- $\alpha$ in vitro 12 secretion by CD4+ T cells. In conclusion, the relative potency of the three helper epitopes in 13 activating $\mathrm{T}$ cell responses in vivo differed considerably (see Table 1). Comparable 14 magnitudes of CD8+ and CD4+ T cell responses were activated by the S238-encoding vector 15 and a more focused response to $\mathrm{CD} 4+$ or $\mathrm{CD} 8+\mathrm{T}$ cell activation with vectors containing 16 PADRE or X26 epitopes, respectively. 


\section{4. Discussion}

Significant efforts are being made to develop effective therapeutic vaccines against

3 chronic infectious diseases [19], and CD8 $+\mathrm{T}$ cells play a crucial role in the control of viral infections. Because CD4+ T cells participate at various stages of CD8+ T-cell responses, it is important to characterize potent $\mathrm{T}$ helper epitopes and to study their role in the induction of anti-infectious CD8+ T-cell responses in vivo.

Ii-chain based vectors have been used to deliver T helper peptides in the MHC class II compartment (MIIC) in order to enhance their presentation to $\mathrm{T}$ cells and improve vaccine formulation [20-24]. In the present study, we chose such vectors to investigate the immune response specific to DRB1*0101-restricted $\mathrm{T}$ helper epitopes X26 and S238 derived respectively from $\mathrm{HBx}$ protein and the PreS2 domain of the HBV envelope protein, and to characterize their potential to help the development of CD8+ T cells. The "promiscuous" PADRE peptide designed to bind multiple HLA class II molecules was also tested as a comparison. Each T helper epitope was inserted downstream of the Ii chain and upstream of two reporter HLA-A*0201-restricted CD8+ T cell epitopes derived from HBV envelope protein. We found a marked difference in the relative potency of the three helper epitopes in activating CD8+ T-cell responses in vivo. Mice transgenic for human class I and class II HLA molecules immunized with the HBV-T helper constructs developed a significantly higher frequency of IFN- $\gamma$-secreting CD8 $+\mathrm{T}$ cells specific to the reporter epitopes than mice immunized with a control construct containing the PADRE peptide. In addition, the functionality and diversity of the immune responses were dependent on the $\mathrm{T}$ helper epitope present in the vector used for immunization.

The efficient presentation of MHC class II-restricted epitopes by MHC class II molecules to $\mathrm{CD} 4+\mathrm{T}$ cells is a process that requires different steps. In particular, in the endoplasmic reticulum, MHC class II molecules assemble and bind with the Ii chain. This Ii 
1 chain is crucial to the efficient presentation of MHC class II-restricted epitopes because of its

2 ability to exchange the CLIP peptide with antigenic peptide in the MIIC in order to load the

3 MHC class II molecule. Ii chain-based vectors should favor the development of CD4+ T cell

4 responses addressing the epitope to the MIIC compartment. We have also assumed that some

5 mistranslated recombinant invariant chains (DRIPS or defective ribosomal products) may be

6 processed cytosolically for presentation by MHC class I molecules, thus allowing

7 establishment of the CD8+ T cell response [25].

During this study, the primed CD8 $+\mathrm{T}$ cell response differed first of all in terms of its intensity. Compared with the PADRE-containing vector, DNA constructs which contained HBV-derived $\mathrm{T}$ helper epitopes stimulated a higher frequency of CD8+ $\mathrm{T}$ cells secreting IFN $\gamma$. The CD8+ T cell response also varied according to the reporter epitope; HBs 348-357specific pluri-functional CD8 $+\mathrm{T}$ cells were detected in mice immunized with all the constructs whereas HBs 335-343-specific CD8+ T cells secreting IFN- $\gamma$ were only detected at a low frequency in a few mice. This epitope had previously been found to be subdominant in HLA-A*0201 transgenic mice immunized with a DNA plasmid encoding full-length HBV envelope proteins [17]. Competition for MHC class I binding between HBs 335-343 and HBs 348-357, an immunodominant epitope in the HLA-A*0201 context, could explain this weak response. Basal levels of IFN- $\gamma$-secreting $\mathrm{T}$ cells were observed after the HBs 348-357 stimulation of splenocytes from mice immunized with the pIC-Empty construct but not from non-immunized mice (Fig. 3). However, in a previous study using similar constructs, the

21 CD8+ T cell response against HLA-A*0201-restricted reporter epitopes had also been higher than expected [20]. The absence of CLIP peptide in the pIC-Empty construct may have generated a larger amount of DRIPs providing peptides for class I loading. Otherwise, recent studies have shown that signals derived from the triggering of TLR ligands can bypass the need for CD4+ T-cell help in the in vivo induction of fully efficient effector and memory 
1 CD8+ T cells [26-29]. Such "helpless" CD8+ T cells may have been generated by the CpG

2 motifs contained in our DNA constructs that are known to trigger TLR9. Importantly, the

3 primed $\mathrm{CD} 8+\mathrm{T}$ cell response also differed regarding its functionality, depending on the $\mathrm{T}$

4 helper epitope present in the construct used for immunization. Even though the frequency of

5 HBs 348-357-specific CD8 $+\mathrm{T}$ cells detected after pentamer staining was not significantly

6 different in responder mice (Fig. 2), the quality of response measured by cytokine secretion,

7 CD107a degranulation marker and cytotoxicity differed between constructs. For example, comparable percentages of pentamer-positive T cells were found following pIC-PADRE, pICS238 and pIC-X26 immunization. However, the mean percentage of IFN- $\gamma$-secreting-HBs 348-357-specific CD8+ T cells with cytotoxic function was higher in pIC-S238- and pIC-

11 X26-immunized mice compared with those immunized with pIC-PADRE (Fig. 4B). Following immunization with pIC-S238 and pIC-PADRE, mice developed CD4+ T cells secreting IFN- $\gamma$, TNF- $\alpha$ and IL-2 after stimulation with the cognate peptides (Fig. 5 and 6). Interestingly, whereas pIC-X26 activated significantly larger numbers of HBs 348-357specific IFN- $\gamma$-secreting CD8 $+\mathrm{T}$ cells than the pIC-Empty or pIC-PADRE constructs, no X26-specific CD4+ T cells were detected during our assays, whatever the cytokine tested. Several hypotheses can be put forward to explain this discrepancy, i.e. i) a low frequency of X26-specific circulating CD4+ T cells; ii) an earlier kinetic of activation of these cells making them undetectable at the time of our assay; iii) post-translational modifications occurring in cells expressing the pIC-X26 construct [30]; iv) the emergence of neoepitopes translated from overlapping sequences adjacent to X26 in the construct and competing with $\mathrm{X} 26$ for recognition by CD4+ T cells [31]. This result was particularly surprising knowing that X26specific CD4+ T cell responses were easily detectable in PBMC from HBV-infected patients. Differences in the processing of the X26 epitope expressed by the Ii-based DNA vector in 25 mice and in the full length $\mathrm{HBx}$ protein during infection in human may explain this 
1 discrepancy. In addition, the reactivity of the X26 peptide could be limited by the size

2 of its specific repertoire of CD4+ T lymphocytes in mice, with a low frequency of $\mathrm{T}$

3 cells able to recognize this peptide being present in mice. In contrast, high responder

4 peptides such as PADRE could correspond to epitopes with a large number of CD4+ T-cell precursors. The relative weak immunogenicity of $\mathrm{HBx} 26 \mathrm{~T}$ helper epitope compared to the PADRE epitope is unlikely to result from different affinity, as both peptides bound to HLA-DR1 molecules with comparable efficiency in in-vitro binding assays [7], [11].

The quality of both $\mathrm{CD} 4+$ and $\mathrm{CD} 8+\mathrm{T}$ cell responses is more important than their magnitude to maintaining a low level of persistence or eliminating a virus from the body, as 11 reviewed by Seder et al. [32]. Although, we did not assessed cytokine production in a single assay, we showed here that HBV-derived $\mathrm{T}$ helper epitope containing constructs could activate $\mathrm{CD} 8+$ and/or CD4+ T cells with multiple functions in mice transgenic for MHC class I and class II molecules. With a PADRE-containing construct, the response mainly focused on the strong activation of CD4+ T cells secreting IFN- $\gamma$, IL-2 and TNF- $\alpha$. PADRE is a synthetic epitope and its sequence has been optimized to ensure efficient binding to numerous HLA DR class II molecules and certain mouse class II alleles [11]. This universal helper epitope has been used in various studies on cancer or infectious diseases in order to improve the specific immune response in a context of vaccine strategies. Its helper function has been well characterized in mice, but to a lesser extent in humans [33-35]. Despite the efficient CD4+ T cell response developed against the PADRE epitope in HLA-DR1 transgenic mice, we did not observe a stronger activation of the effector CD8+ T cell immune response than that observed with HBV-derived $\mathrm{T}$ helper epitopes. The low induction of CD8+ T cells, despite the

24 induction of a large number of PADRE-specific CD4+ T cells, was probably not 
1 related to the induction of regulatory $\mathrm{T}$ cells that may control CD8+ T-cell expansion

2 [23]. Otherwise, it is possible that immunization with the PADRE-containing vector

3 affected CD8+ T-cell survival by triggering activation-induced cell death, possibly

4 through cytokines or Fas/FasL.

The induction of HBV-specific CD4+ T cells may be of physiological importance to resolving infection in $\mathrm{HBV}$-infected patients with chronic hepatitis who often display functionally impaired CD8+ $\mathrm{T}$ cell responses [36, 37]. In this setting, the X26- and S238specific CD4+ $\mathrm{T}$ cells that were characterized during our study could provide in vivo assistance in the development of anti-viral CD8+ T cell responses. HBx is a regulatory protein that is expressed and required during the initial steps of viral replication. The development of an $\mathrm{HBx}$-specific $\mathrm{T}$ helper response in a large number of patients with low viremia has suggested a role for an X26-specific response and an associated CD8+ T-cell response in the control of viral replication [7]. The emergence of mutations affecting epitope recognition during reactivation of a disease supports this hypothesis [7]. The S238 epitope is clearly a good candidate to help with the development of an HBV-specific CD8 $+\mathrm{T}$ cell immune response. It has also been shown to activate $\mathrm{CD} 4+\mathrm{T}$ cells from hepatitis $\mathrm{B}$ vaccinated patients [8] and this response may be linked to development of a protective anti-HBs response. The importance of the preS2 domain in providing $\mathrm{T}$ cell help to the $\mathrm{B}$ cell response was largely demonstrated in mice by Milich et al. [38]. Th1 cytokines produced by both S238-specific CD4+ T cells and HBs 348-357-specific CD8+ T cells may be of clinical significance, as such cytokines are implicated in viral control [4]. Patients with acute HBV infection that resolves spontaneously develop multispecific functional CD8+ and CD4+ T cell responses. The inclusion of S238 and X26 epitopes in therapeutic vaccine formulations may restore a multifunctional response, helping in the development of strong CD8+ Th1 immune responses that can diminish the viral load. 


\section{ACKNOWLEDGEMENTS}

2 We would like to thank Florence Buseyne, Lisa Chakrabarti and Bernard Maillère for critical

3 scientific discussions.

4 This work and Silvina Malmassari's fellowship were supported by grants from Agence

5 Nationale pour la Recherche (ANR). Florence Bayard holds a fellowship from Agence

6 Nationale de Recherche contre le SIDA et les hepatites virales (ANRS) and from Association

7 pour la Recherche sur le Cancer (ARC). Qiang Deng's fellowship was supported by Conseil

8 regional d'Ile de France.

9 


\section{REFERENCES}

3 [1] Dienstag JL. Hepatitis B virus infection. N Engl J Med 2008 Oct 2;359(14):1486-500.

4 [2] Chang JJ, Lewin SR. Immunopathogenesis of hepatitis B virus infection. Immunol 5 Cell Biol 2007 Jan;85(1):16-23.

6 [3] Rehermann B, Nascimbeni M. Immunology of hepatitis B virus and hepatitis C virus 7 infection. Nat Rev Immunol 2005 Mar;5(3):215-29.

8 [4] Guidotti LG, Chisari FV. Immunobiology and pathogenesis of viral hepatitis. Annu $9 \quad$ Rev Pathol 2006;1:23-61.

10 [5] Castellino F, Germain RN. Cooperation between CD4+ and CD8+ T cells: when, 11 where, and how. Annu Rev Immunol 2006;24:519-40.

12 [6] Ganem D, Prince AM. Hepatitis B virus infection--natural history and clinical 13 consequences. N Engl J Med 2004 Mar 11;350(11):1118-29.

14 [7] Malmassari SL, Deng Q, Fontaine H, Houitte D, Rimlinger F, Thiers V, et al. Impact 15 of hepatitis B virus basic core promoter mutations on $\mathrm{T}$ cell response to an immunodominant HBx-derived epitope. Hepatology 2007 May;45(5):1199-209.

17 [8] Pajot A, Michel ML, Mancini-Bourgine M, Ungeheuer MN, Ojcius DM, Deng Q, et 18 al. Identification of novel HLA-DR1-restricted epitopes from the hepatitis B virus envelope protein in mice expressing HLA-DR1 and vaccinated human subjects. Microbes Infect 2006 Oct;8(12-13):2783-90.

21 [9] Sponaas A, Carstens C, Koch N. C-terminal extension of the MHC class II-associated 22 invariant chain by an antigenic sequence triggers activation of naive T cells. Gene Ther 1999 23 Nov;6(11):1826-34.

24 [10] Freisewinkel IM, Schenck K, Koch N. The segment of invariant chain that is critical 25 for association with major histocompatibility complex class II molecules contains the 
1 sequence of a peptide eluted from class II polypeptides. Proc Natl Acad Sci U S A 1993 Oct $2 \quad 15 ; 90(20): 9703-6$.

3 [11] Alexander J, Sidney J, Southwood S, Ruppert J, Oseroff C, Maewal A, et al.

4 Development of high potency universal DR-restricted helper epitopes by modification of high

5 affinity DR-blocking peptides. Immunity 1994 Dec;1(9):751-61.

6 [12] Pajot A, Michel ML, Fazilleau N, Pancre V, Auriault C, Ojcius DM, et al. A mouse 7 model of human adaptive immune functions: HLA-A2.1-/HLA-DR1-transgenic H-2 class I8 /class II-knockout mice. Eur J Immunol 2004 Nov;34(11):3060-9.

9 [13] Michel ML, Davis HL, Schleef M, Mancini M, Tiollais P, Whalen RG. DNAmediated immunization to the hepatitis B surface antigen in mice: aspects of the humoral

11 response mimic hepatitis B viral infection in humans. Proc Natl Acad Sci U S A 1995 Jun 6;92(12):5307-11.

[14] Mancini-Bourgine M, Bayard F, Soussan P, Deng Q, Lone YC, Kremsdorf D, et al. Hepatitis B virus splice-generated protein induces T-cell responses in HLA-transgenic mice and hepatitis B virus-infected patients. J Virol 2007 May;81(10):4963-72.

[15] Nayersina R, Fowler P, Guilhot S, Missale G, Cerny A, Schlicht HJ, et al. HLA A2 restricted cytotoxic $\mathrm{T}$ lymphocyte responses to multiple hepatitis $\mathrm{B}$ surface antigen epitopes during hepatitis B virus infection. J Immunol 1993 May 15;150(10):4659-71. cytotoxic T lymphocyte response to multiple hepatitis B virus polymerase epitopes during and

21 after acute viral hepatitis. J Exp Med 1995 Mar 1;181(3):1047-58.

22 [17] Loirat D, Lemonnier FA, Michel ML. Multiepitopic HLA-A*0201-restricted immune response against hepatitis B surface antigen after DNA-based immunization. J Immunol 2000 
1 [18] Betts MR, Brenchley JM, Price DA, De Rosa SC, Douek DC, Roederer M, et al.

2 Sensitive and viable identification of antigen-specific CD8 $+\mathrm{T}$ cells by a flow cytometric

3 assay for degranulation. J Immunol Methods 2003 Oct 1;281(1-2):65-78.

4 [19] Ha SJ, West EE, Araki K, Smith KA, Ahmed R. Manipulating both the inhibitory and

5 stimulatory immune system towards the success of therapeutic vaccination against chronic

6 viral infections. Immunol Rev 2008 Jun;223:317-33.

7 [20] Pajot A, Schnuriger A, Moris A, Rodallec A, Ojcius DM, Autran B, et al. The Th1 8 immune response against HIV-1 Gag p24-derived peptides in mice expressing HLA-A02.01

9 and HLA-DR1. Eur J Immunol 2007 Sep;37(9):2635-44.

10 [21] Kim D, Hoory T, Monie A, Ting JP, Hung CF, Wu TC. Enhancement of DNA vaccine 11 potency through coadministration of CIITA DNA with DNA vaccines via gene gun. J 12 Immunol 2008 May 15;180(10):7019-27.

13 [22] Kim D, Monie A, He L, Tsai YC, Hung CF, Wu TC. Role of IL-2 secreted by PADRE-specific CD4+ T cells in enhancing E7-specific CD8+ T-cell immune responses. Gene Ther 2008 May;15(9):677-87.

16 [23] Hung CF, Tsai YC, He L, Wu TC. DNA vaccines encoding Ii-PADRE generates 17 potent PADRE-specific CD4+ T-cell immune responses and enhances vaccine potency. Mol Ther 2007 Jun;15(6):1211-9.

[24] Radcliffe JN, Roddick JS, Friedmann PS, Stevenson FK, Thirdborough SM. Primeboost with alternating DNA vaccines designed to engage different antigen presentation 21 pathways generates high frequencies of peptide-specific CD8+ T cells. J Immunol 2006 Nov $22 \quad 15 ; 177(10): 6626-33$.

23 [25] Shastri N, Cardinaud S, Schwab SR, Serwold T, Kunisawa J. All the peptides that fit: 24 the beginning, the middle, and the end of the MHC class I antigen-processing pathway. 25 Immunol Rev 2005 Oct;207:31-41. 
1 [26] Hervas-Stubbs S, Olivier A, Boisgerault F, Thieblemont N, Leclerc C. TLR3 ligand 2 stimulates fully functional memory CD8+ T cells in the absence of CD4+ T-cell help. Blood 32007 Jun 15;109(12):5318-26.

4 [27] Assudani D, Cho HI, DeVito N, Bradley N, Celis E. In vivo expansion, persistence, 5 and function of peptide vaccine-induced CD8 T cells occur independently of CD4 T cells. 6 Cancer Res 2008 Dec 1;68(23):9892-9.

7 [28] Higgins D, Marshall JD, Traquina P, Van Nest G, Livingston BD. Immunostimulatory DNA as a vaccine adjuvant. Expert Rev Vaccines 2007 Oct;6(5):747-59.

9 [29] Agnellini P, Wiesel M, Schwarz K, Wolint P, Bachmann MF, Oxenius A. Kinetic and mechanistic requirements for helping CD8 T cells. J Immunol 2008 Feb 1;180(3):1517-25.

11 [30] Engelhard VH, Altrich-Vanlith M, Ostankovitch M, Zarling AL. Post-translational modifications of naturally processed MHC-binding epitopes. Curr Opin Immunol 2006 Feb;18(1):92-7.

14 [31] Livingston B, Crimi C, Newman M, Higashimoto Y, Appella E, Sidney J, et al. A rational strategy to design multiepitope immunogens based on multiple Th lymphocyte 16 epitopes. J Immunol 2002 Jun 1;168(11):5499-506.

17 [32] Seder RA, Darrah PA, Roederer M. T-cell quality in memory and protection: implications for vaccine design. Nat Rev Immunol 2008 Apr;8(4):247-58.

[33] Ishioka GY, Fikes J, Hermanson G, Livingston B, Crimi C, Qin M, et al. Utilization of MHC class I transgenic mice for development of minigene DNA vaccines encoding multiple

21 HLA-restricted CTL epitopes. J Immunol 1999 Apr 1;162(7):3915-25.

22 [34] Livingston BD, Alexander J, Crimi C, Oseroff C, Celis E, Daly K, et al. Altered helper 23 T lymphocyte function associated with chronic hepatitis $\mathrm{B}$ virus infection and its role in 24 response to therapeutic vaccination in humans. J Immunol 1999 Mar 1;162(5):3088-95. 
1 [35] Gorse GJ, Baden LR, Wecker M, Newman MJ, Ferrari G, Weinhold KJ, et al. Safety

2 and immunogenicity of cytotoxic T-lymphocyte poly-epitope, DNA plasmid (EP HIV-1090)

3 vaccine in healthy, human immunodeficiency virus type 1 (HIV-1)-uninfected adults. Vaccine

42008 Jan 10;26(2):215-23.

5 [36] Bertoletti A, Gehring AJ. The immune response during hepatitis B virus infection. J

6 Gen Virol 2006 Jun;87(Pt 6):1439-49.

7 [37] Boni C, Fisicaro P, Valdatta C, Amadei B, Di Vincenzo P, Giuberti T, et al.

8 Characterization of hepatitis B virus (HBV)-specific T-cell dysfunction in chronic HBV

9 infection. J Virol 2007 Apr;81(8):4215-25.

10 [38] Milich DR, Thornton GB, Neurath AR, Kent SB, Michel ML, Tiollais P, et al.

11 Enhanced immunogenicity of the pre-S region of hepatitis B surface antigen. Science 1985

12 Jun 7;228(4704):1195-9.

13

14 
1 Table 1. Summary of CD8+ and CD4+ T cell responses from mice immunized with the $\mathrm{T}$

2 helper constructs. $p$ values between groups are indicated for each assay.

\begin{tabular}{|c|c|c|c|c|}
\hline \multicolumn{2}{|c|}{ T helper epitopes } & HBV-X26 & HBV-S238 & PADRE \\
\hline \multirow{4}{*}{$\begin{array}{c}\text { CD8+ } \\
\text { T cell } \\
\text { responses }\end{array}$} & $\begin{array}{c}\text { HBs 348-357 } \\
\text { Pentamer +cells: } \\
\text { magnitude of response }\end{array}$ & $\mathrm{NS}^{b}$ & $\mathrm{NS}$ & NS \\
\hline & Number of responder mice & $13 / 24$ & $\begin{array}{c}19 / 20 \\
S 238>X 26 \\
p=0.0027^{c}\end{array}$ & $\begin{array}{c}10 / 10 \\
\text { PADRE }>\text { X26 } \\
p=0.0135\end{array}$ \\
\hline & $\begin{array}{c}\text { HBs348-357 } \\
\text { IFN- } \gamma \text {-CD8+ T cells: } \\
\text { magnitude of response }\end{array}$ & $\begin{array}{c}\mathrm{X} 26>\mathrm{PADRE} \\
\mathrm{p}=0.0003\end{array}$ & $\begin{array}{c}\text { S238 }>\text { PADRE } \\
\mathrm{p}=0.0003\end{array}$ & \\
\hline & Number of responder mice & $\begin{array}{c}27 / 30 \\
\text { NS }\end{array}$ & $\begin{array}{c}18 / 20 \\
\mathrm{NS}\end{array}$ & $\begin{array}{c}11 / 15 \\
\mathrm{NS}\end{array}$ \\
\hline
\end{tabular}

\begin{tabular}{|c|c|c|c|c|}
\hline & $\begin{array}{l}\text { IFN- } \gamma-\mathrm{CD} 4+\mathrm{T} \text { cells: } \\
\text { magnitude of response }\end{array}$ & & $\begin{array}{l}\mathrm{S} 238>\mathrm{X} 26 \\
\mathrm{p}<0.0001\end{array}$ & $\begin{array}{c}\text { PADRE }>\text { X } 26 \\
\mathrm{p}<0.0001\end{array}$ \\
\hline & Number of responder mice & $0 / 30$ & $\begin{array}{c}18 / 20 \\
\mathrm{~S} 238>\mathrm{X} 26 \\
\mathrm{p}<0.0001\end{array}$ & $\begin{array}{c}13 / 15 \\
\text { PADRE }>\text { X } 26 \\
p<0.0001\end{array}$ \\
\hline & $\begin{array}{l}\text { IL-2- CD4+ T cells: } \\
\text { magnitude of response }\end{array}$ & & $\begin{array}{l}\mathrm{S} 238>\mathrm{X} 26 \\
\mathrm{p}<0.0001\end{array}$ & $\begin{array}{c}\text { PADRE }>\text { X26 } \\
p<0.0001\end{array}$ \\
\hline $\begin{array}{c}\text { CD4+ } \\
\text { T cell } \\
\text { responses }\end{array}$ & & & & $\begin{array}{c}\text { PADRE }>\text { S238 } \\
p=0.001\end{array}$ \\
\hline & Number of responder mice & $0 / 24$ & $\begin{array}{c}15 / 20 \\
S 238>X 26 \\
p<0.0001\end{array}$ & $\begin{array}{c}14 / 15 \\
\text { PADRE }>\text { X } 26 \\
p<0.0001\end{array}$ \\
\hline & $\begin{array}{l}\text { TNF- } \alpha-C D 4+T \text { cells: } \\
\text { magnitude of response }\end{array}$ & & $\begin{array}{c}\mathrm{S} 238>\mathrm{X} 26 \\
\mathrm{p}=0.0013\end{array}$ & $\begin{array}{c}\text { PADRE }>X 26 \\
p=0.0005\end{array}$ \\
\hline & Number of responder mice & $0 / 6$ & $\begin{array}{c}6 / 8 \\
S 238>X 26 \\
p=0.0097\end{array}$ & $\begin{array}{c}9 / 10 \\
\text { PADRE }>\text { X } 26 \\
p=0.0009\end{array}$ \\
\hline
\end{tabular}




\section{$1 \quad$ Legends to Figures}

2

3 Fig. 1: DNA constructs used in this study: A) in pIC-Empty, expression of the mouse

Fig. 2: Ex vivo HLA-A*0201 pentamer staining. Staining for T cells specific to the two HLAA2 reporter epitopes (HBs 348-357 and HBs 335-343) was performed on freshly isolated splenocytes from immunized mice 10 days after the second immunization. A) Bars represent mean values $+/-$ SEM of $\%$ of pentamer HBs $348-357+\mathrm{CD} 3+\mathrm{CD} 8+\mathrm{T}$ cells from responder mice after subtraction of background values obtained with HBV core 18-27 pentamer staining. The number of responder mice is indicated above the bars. B) Representative example of pentamer staining for HBs 348-357-(right panel) and HBV core 18-27-(left panel) specific $\mathrm{T}$ cells on splenocytes from a mouse immunized with pIC-S238. C) Bars represent mean values +/- SEM of pentamer HBs 335-343+CD3+CD8+ T cells of responder mice after subtraction of background values. The number of responder mice is indicated above the bars.

Fig. 3 : Induction of IFN- $\gamma$-secreting HBs-specific T cells. HLA-A*0201/HLA-DRB1*0101 double transgenic mice were immunized twice and an ex vivo ELISPOT assay for IFN- $\gamma$ secretion was performed 10 days after the second injection of the DNA constructs indicated. HBs 348-357 (A) or HBs 335-343 (B) peptides were used for ex vivo stimulation of splenocytes from DNA-immunized or non-immunized mice. Each symbol represents an 
1 individual mouse. Mean values +/- SEM of SFC per million splenocytes from all mice tested

2 in each immunization group are indicated by bars. Statistically $(p<0.05)$ and non-statistically

3 (ns) significant differences evaluated by the Mann-Whitney test are reported on graphs.

Fig. 4: Ex vivo staining for CD107a and IFN- $\gamma$. Mice were immunized with pIC-PADRE $(\mathrm{n}=10), \mathrm{pIC}-\mathrm{X} 26(\mathrm{n}=8)$ and pIC-S238 $(\mathrm{n}=10)$ constructs. A) Representative CD107a and IFN$\gamma$ staining of splenocytes from a mouse immunized with pIC-S238 $\mathrm{T}$ helper construct after incubation with HBs 348-357 peptide (right panel) or medium (left panel). B) Mean values +/SEM of $\%$ of IFN- $\gamma+\mathrm{CD} 107 \mathrm{a}+\mathrm{CD} 3+\mathrm{CD} 8+$ HBs 335-343- or HBs 348-357-specific T cells among the CD8 $+\mathrm{T}$ cells from immunized mice after the subtraction of background obtained with $\mathrm{T}$ cells in medium alone. C) Flow cytometric profile of in vivo cytotoxic killing of CFSE-labeled target cells loaded with HBs 335-343 (low), HBs 348-357 (Int) or control peptide (high). The \% of CFSE-labeled cells detected in spleen from a naïve mouse (left panel) or from a pIC-S238-immunized mouse (right panel) are indicated.

15

Fig. 5: IFN- $\gamma$ and IL-2 production after T helper peptide stimulation. Helper peptides PADRE, S238 and X26 were used to stimulate splenocytes from respectively pIC-PADRE, pIC-S238 and pIC-X26 immunized mice. IFN- $\gamma-(\mathrm{A})$ and IL-2-(B) secreting T cells specific to the T helper epitopes were detected by ELISPOT assay. Each symbol corresponds to the value obtained for an individual mouse. Means +/- SEM of SFC per million splenocytes are indicated by bars. Statistically $(p<0.05)$ and non-statistically (ns) significant differences evaluated by the Mann-Whitney test are reported on graphs.

Representative figure of flow cytometry data on splenocytes from mice immunized with pICPADRE (C). Spleen cells were stimulated with PADRE peptide to assess intracellular IFN- $\gamma$ production and surface-labeled with specific anti-CD3, CD4, CD8 T-cell antibodies (right 
1 panel). Splenocytes in medium but without peptide stimulation were used as negative controls 2 (left panel).

4 Fig. 6: TNF- $\alpha$ staining of splenocytes from mice immunized with pIC-PADRE, pIC-S238 and 5 pIC-X26. Spleen cells were stimulated with PADRE, S238 and X26 peptides to assess TNF- $\alpha$

6 secretion by specific CD3+CD4+ T cells. Bars correspond to means +/- SEM of \%TNF$7 \alpha+\mathrm{CD} 3+\mathrm{CD} 4+$ peptide-specific $\mathrm{T}$ cells among the CD3+CD4+ $\mathrm{T}$ cells from immunized mice 8 after the subtraction of background values. Statistically $(p<0.05)$ and non-statistically (ns) 9 significant differences evaluated by the Mann-Whitney test are reported on graphs.

10

11 Fig. 7: Functional diversity of $\mathrm{T}$ cell responses activated by injection of the $\mathrm{T}$ helper constructs. Elispot assays were performed after the stimulation of splenocytes with HBs 348357 (A) and HBs 335-343 (B) peptide (IFN- $\gamma$ - and IL-2-secreting CD8+ T cells) or with each

14 T helper epitope (IFN- $\gamma$ - and IL-2-secreting CD4+ T cells). Sum of means of SFC per million 15 splenocytes from mice immunized with pIC-Empty, pIC-PADRE, pIC-S238 and pIC-X26, 16 are represented. 
A pIC-Empty

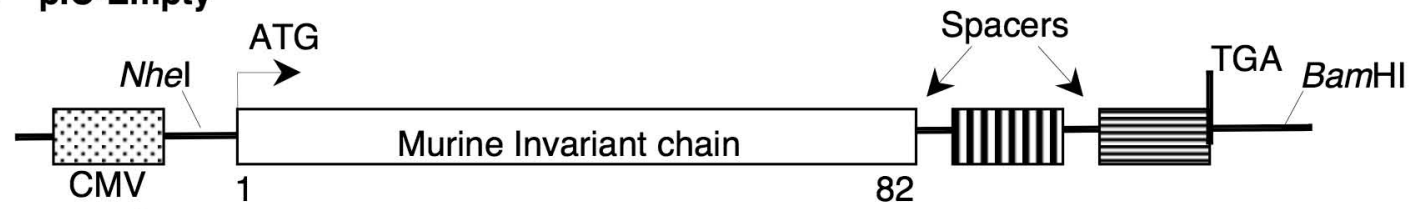

promoter

[Z] Thelper epitope

IIIIII HBs 335-343

豆 HBs 348-357

B T helper constructs

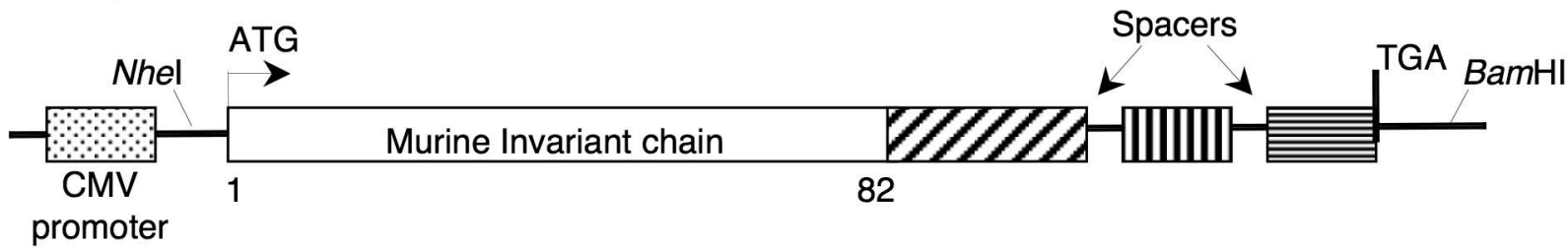

Figure 1, Vaccine, Bayard F. et al 


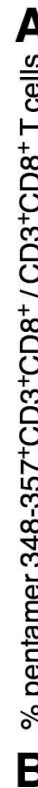

\section{Pentamer HBs 348-357}

B
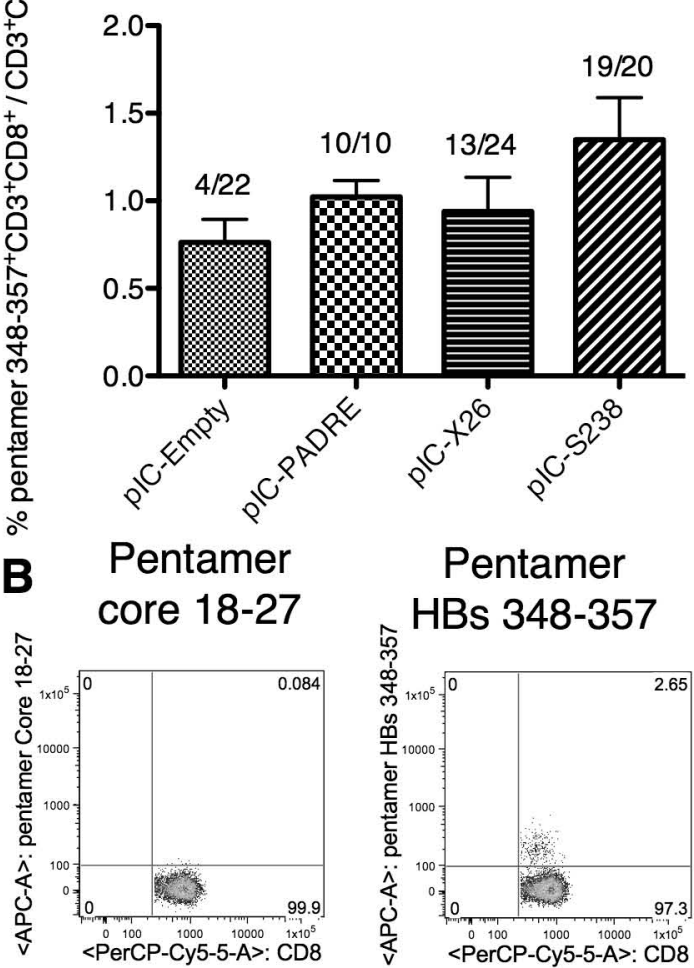

\section{Pentamer \\ Pentamer}

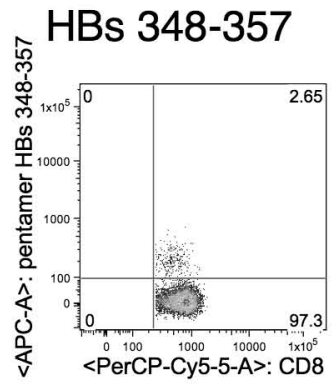

C

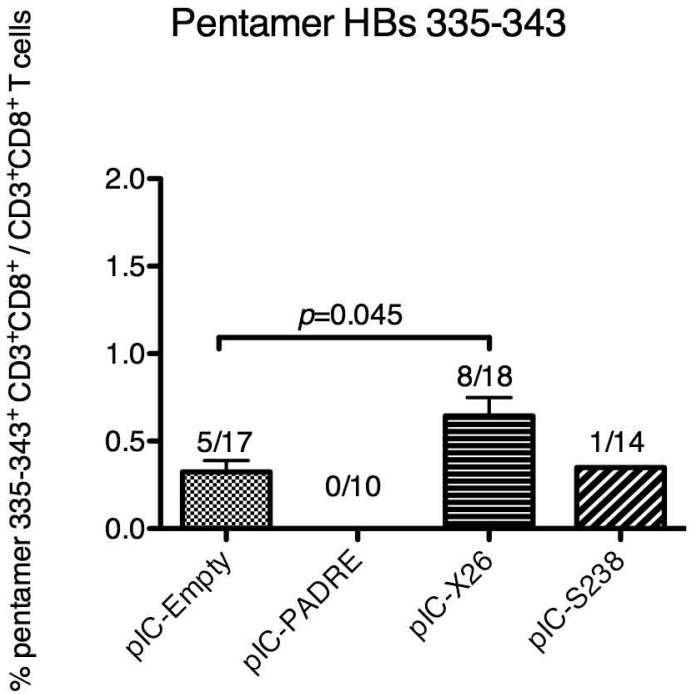

Figure 2, Vaccine, Bayard F. et al 
A IFN- $\gamma$ secretion after $\mathrm{HBs} 348-357$ stimulation

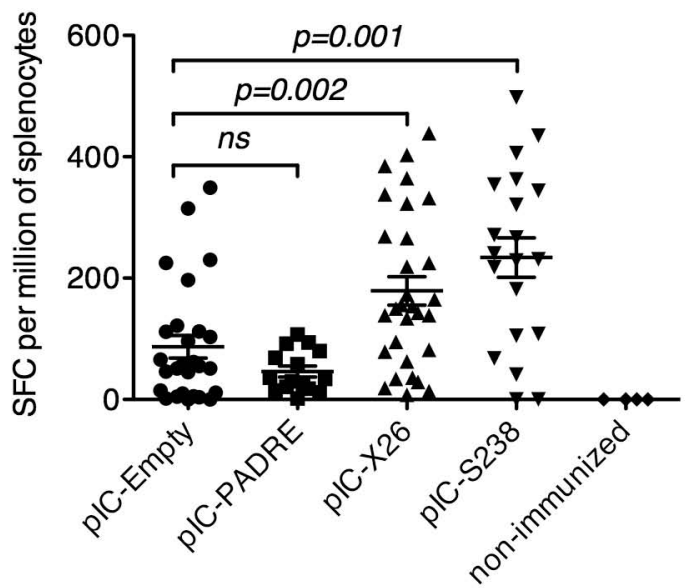

B IFN- $\gamma$ secretion after $\mathrm{HBs} 335-343$ stimulation

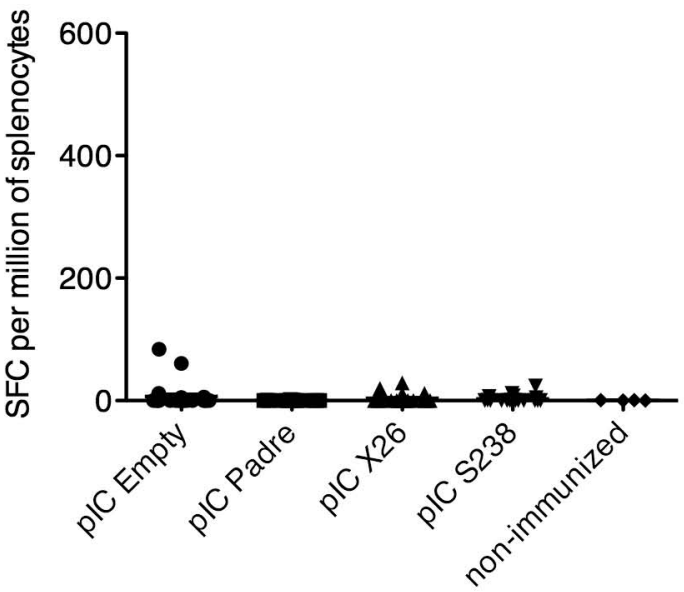

Figure 3, Vaccine, Bayard F. et al 
pIC-S238
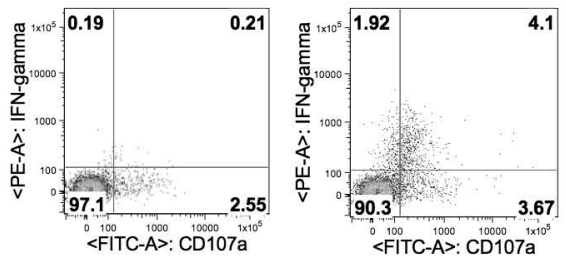

B

乐

$\stackrel{\leftarrow}{+} \quad 2.07 \quad \%$ HBs 335-343

仓

号 $1.5-$

@

$+\infty$

บิ

$+$

@

+

00 HBs 348-357

$1.0-$

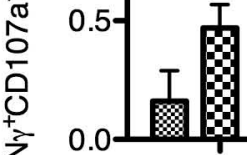

는

o

C naïve

plC-S238

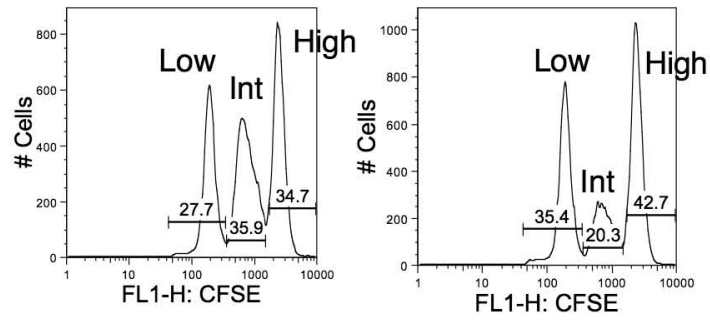

Figure 4, Vaccine, Bayard F. et al 
A IFN- $\gamma$ secretion after Thelper epitopes stimulation

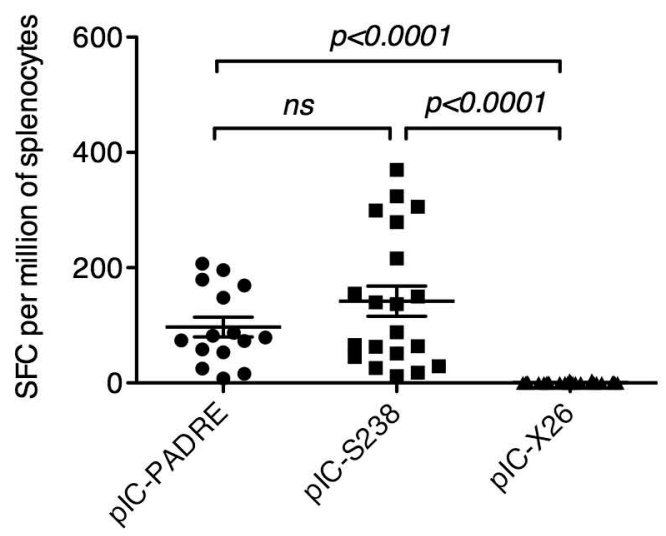

B IL-2 secretion after Thelper epitopes stimulation

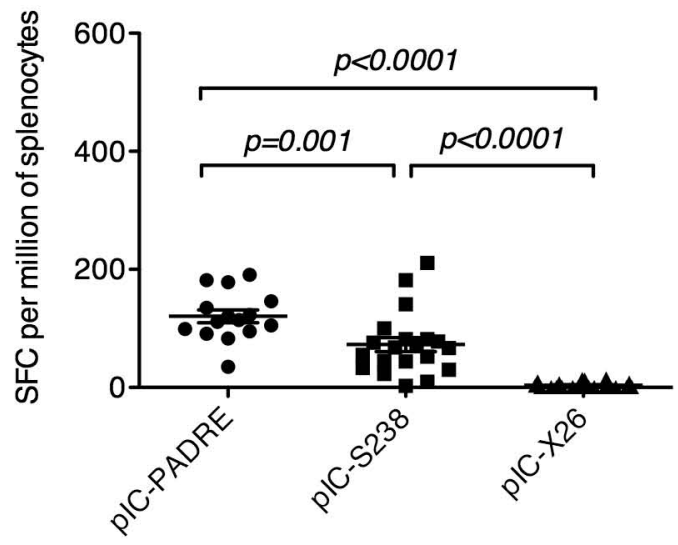

C
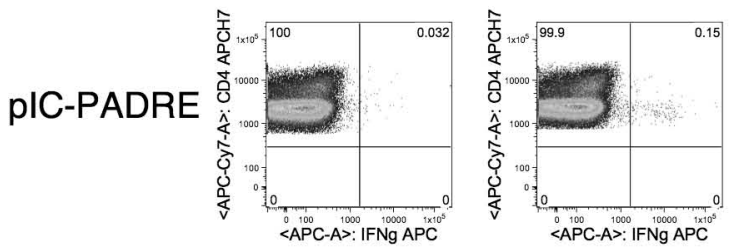

Figure 5, Vaccine, Bayard F. et al 


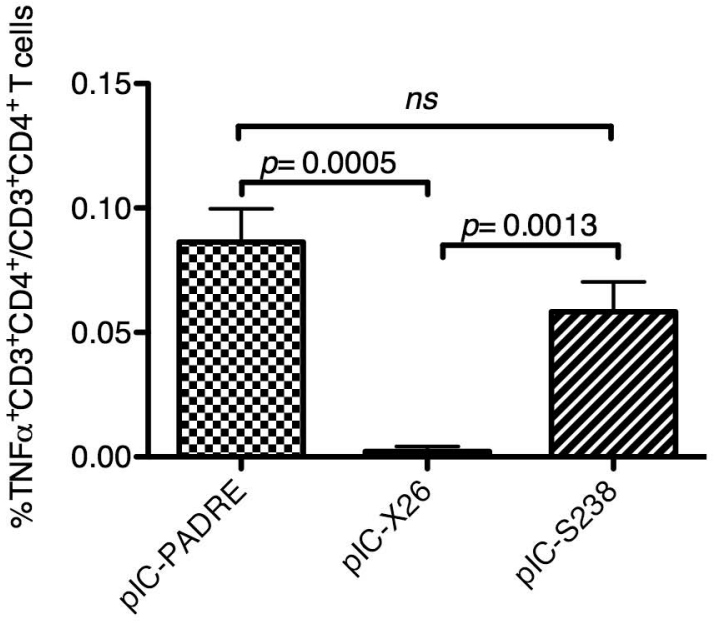

Figure 6, Vaccine, Bayard F. et al 


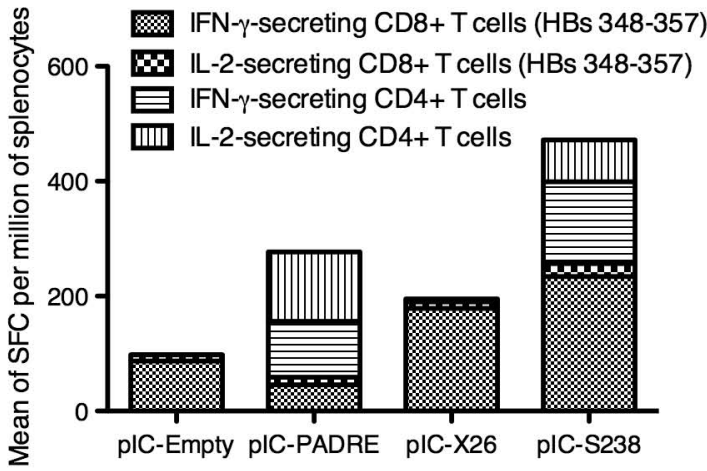

B

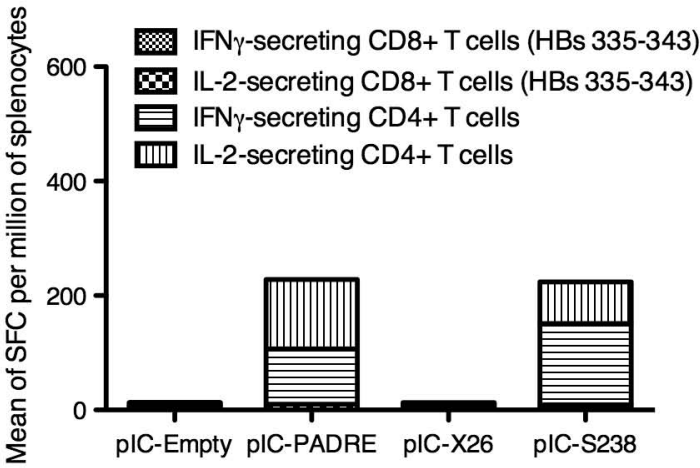

Figure 7, Vaccine, Bayard F. et al 